\title{
Development of an accelerated fatigue tester to evaluate durability performance of vascular stent
}

\author{
$\bigcirc$ 長谷川厚(早大院生生命理工) 正 岩﨑清隆(早大生命医療工学研究所) \\ 錦織晃(早大院生生命理工) 森田祐樹(早大理工機械) 正 梅津光生（早大理工機械)
}

Atsushi HASEGAWA, Akira NISHIKOHRI, Major in Integrative Bioscience and Biomechanical Engineering, Graduate School of Waseda University, \#58-322 3-4-1 Ohkubo, Shinjyuku-ku, Tokyo

Kiyotaka IWASAKI, Institute for Biomedical Engineering, Waseda University

Yuki MORITA, Mitsuo UMEZU, Dept. of Mechanical Engineering, School of Science and Engineering, Waseda University

\section{1. 緒言}

血管内治療における stent $の$ 進歩は目覚しく，低侵襲的医 療と QOL(Quality Of Life)が求められている今日において その重要性及び治療成績はますます高まっている。しかし， 例外的に浅大腿動脈(Superficial femoral artery, 以下 SFA) 病変部一の適用に関しては stent 破損を伴ってしまい，長期 開存性が十分飞得られていない1)。その原因として SFA が 大腿贸管内に位置し，血管屈曲や㸚じれ，圧縮といった生体 力学的負荷の影響を受けやすい環境下に置かれている事に 起因している 2)。このように, 生体力学的負荷と stent の疲 労破壊の関連性が示唆されているにも拘らず, 耐久試験装置 や評価方法は未だに確立されていない，そのため，治療時に おける最適 stent の選定に際しては長期に渡る治療後の追跡 調查が必要となり，また医師の経験や感覚に委ねる要素が強 くなってしまう。そこで本研究では stent の耐久性能を in vitro かつ短期間で評価を行う事を目的とした加速試験疲労 装置の開発及び疲労状態評価方法の検討を行った。

\section{2. 方法}

\section{1 加速屈曲型疲労試験装置の開発}

SFA には複数の負荷が作用しているため, stent 破損を誘 発する主たる負荷要因は判明していない，また， stent の構 造・素材の違いから破損に起因する負荷要因にも相違がある と考えられる. そこで stent 破損と生体力学負荷の関係を単 純化して考えるため, 単一負荷に限定した疲労試験を行う事 とした. その第一段階として，血管屈曲にのみに着目した加 速屈曲型疲労試験装置(Fig.1)を開発した。この装置は (1) Voice Coil Motor 部(Fig.2, 最大推力 76.4[N], 以下 VCM) (2) 内径 $6[\mathrm{~mm}]$ のシリコーン製血管模擬屈曲菅部(Fig.3, Test section)(3温度制御部の三要素から構成されている。リニア モータである VCM の往復運動により, stent 留置する Test section に屈曲角度及び内圧の変動を生み出す仕組みになっ ている. 一例として Fig.4 に，モータストローク $6.5[\mathrm{~mm}]$, 駆動周波数 $40[\mathrm{~Hz}]$ の条件下での $90-150[\mathrm{mmHg}]$ (平均内圧 $120[\mathrm{mmHg}])$ の脈圧波形を示す。

\section{1 加速屈曲疲労試験条件}

繰り返し疲労を高周波で stent に作用する事が出来れば, より短期間での評価が可能となる.しかし本装置は試作段階 であり, 周波数等の最適疲労試験パラメータの確立までは至 っていない,そこで, Table1のように(1)試験周波数を $10[\mathrm{~Hz}]$, ストロークを $5[\mathrm{~mm}]$ に設定した一定サイクル試験(疲労サイ クル 6，12 ケ月相当)と(2)試験周波数を $40[\mathrm{~Hz}]$ ，ストロー クを 6. $5[\mathrm{~mm}]$ に設定した破損試験を行い, 疲労形態の調查 を行った。なお, stentは Boston Secientific 製の Wallstent(最大拡張径 $8[\mathrm{~mm}]$, 全長 $38[\mathrm{~mm}]$ )を利用した.

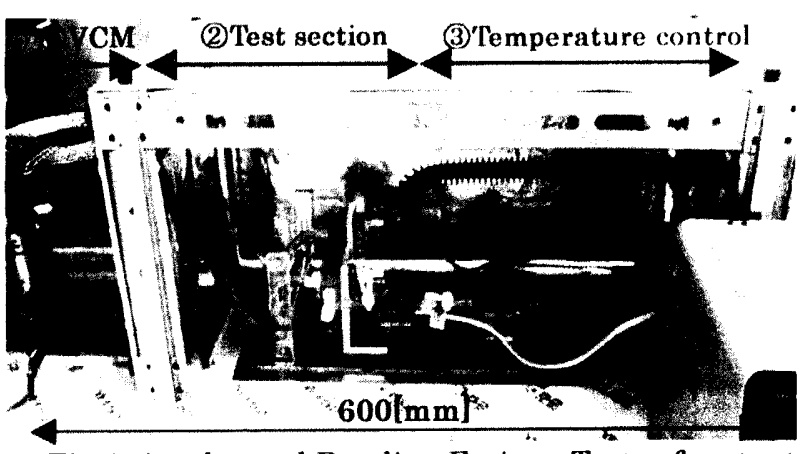

Fig. 1. Accelerated Bending Fatigue Tester for stent
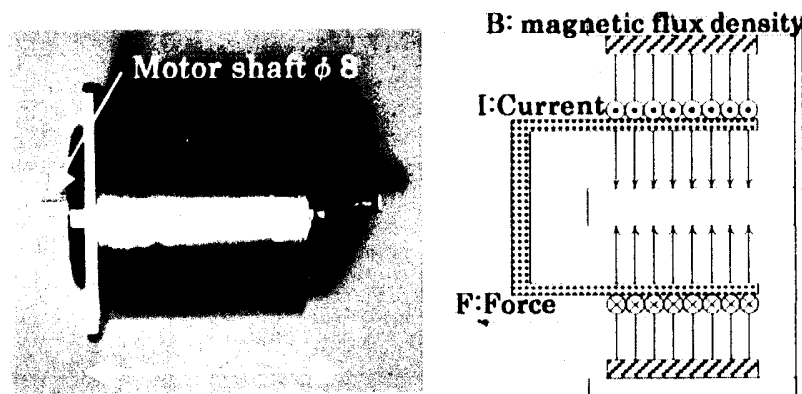

Fig.2. Photograph and drive mechanism of Voice Coil Motor (VCM) ${ }^{3)}$

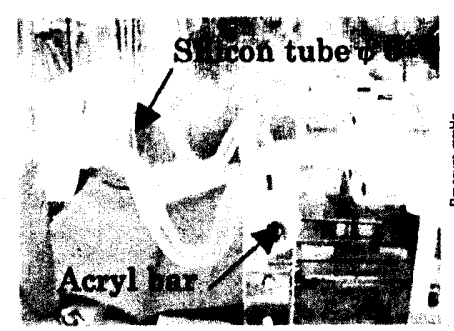

Fig.3 Test section for flexible bending tube

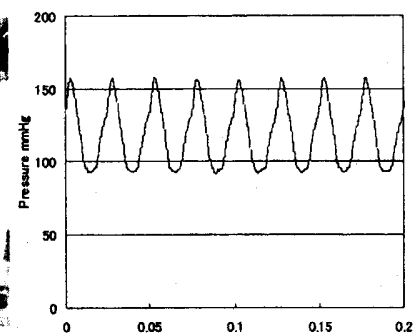

Fig.4 Pressure waveform under the driving frequency of $40 \mathrm{~Hz}$ and motor stroke of $6.5 \mathrm{~mm}$
Table1.Test condition

\begin{tabular}{|c|c|c|c|c|}
\hline Sample & Frequency[Hz] & stroke $[\mathrm{mm}]$ & Angle of bend $\left[{ }^{\circ}\right]$ & Mean pressure[mmHg \\
\hline WALL 48 & 10 & 5 & $90 \pm 4$ & 120 \\
\hline WALL $\varphi 8$ & 10 & 5 & $90 \pm 4$ & 120 \\
\hline WALL $\varphi 8$ & 40 & 6.5 & $90 \pm 5.1$ & 120 \\
\hline & est span & Cycle & Working fluid & Temperature $\left[{ }^{\circ} \mathrm{C}\right]$ \\
\hline & 21.9 & \multirow{2}{*}{$1.89 \times 10^{\wedge} 7$} & \multirow{5}{*}{ PBS } & \multirow{5}{*}{37} \\
\hline equa & 1 to 6 month & & & \\
\hline & 43.8 & \multirow[t]{2}{*}{$3.78 \times 10^{\wedge} 7$} & & \\
\hline equa & to 12 month & & & \\
\hline & - & - & & \\
\hline
\end{tabular}




\section{3. 結果及び考察}

3.1 疲労試験後における SEM 稓察および EPMA(Electron Probe Micro- Analysis)を用いた定性元素分析

疲労周波数を $10[\mathrm{~Hz}]$ に設定した一定サイクル試験では， 試験期間に関わらず破損は観察されなかった。一方, 疲労周 波数を $40[\mathrm{~Hz}]$ に設定した破損試験では, 約 36 ケ月相当の疲 労サイクル時 $\left(1.13 \times 10^{8}\right)$ において Fig.5のような破損を確認 した. Fig.6〜8 に Fig.5 中に示した屈曲引張側 A 部, B 部, stent 破断面 C 部の SEM 及び EPMA 分析結果の一例を示す. なお，SEM 写真中に記した枠領域に内において元素分析も 一つである EPMA 解析を実施した. Fig.7，8に示したよう な破断面や磨耗痕はいずれも stent ストラット接触部にのみ 観察され, それ以外の箇所は未疲労 stent 表面と差は確認さ れなかった. また, Fig.7,8 の破断面・磨耗痕简所において は著しい Ta ピークが検出された. Wall stent のストラット は 6 種類(内訳は $\mathrm{Cr}: 20 \%, \mathrm{Mn}: 2 \%, \mathrm{Fe}: 15 \%, \mathrm{Co}: 40 \%, \mathrm{Ni}: 16 \%$, Mo:7\%)の金属元素からなる ELGILOY 製外周部と直径約 $0.05[\mathrm{~mm}]$ の $\mathrm{Ta}$ 軸心の 2 層構造となっており, クラック深度 と Ta 検出量には相関があると考えられる.このような事か ら EPMA による元素定性分析は SEM 観察と並び, 疲労深 度の検出方法として有効な手段であったといえる.

また，観察部位によるクラック伸展の差は拘束条件の違い により生じたものと推察される. 磨耗の程度が激しかった $\mathrm{B} ・ \mathrm{C}$ 部はアクリル製の円柱型支持棒(Fig.3 矢印部)近傍に集 中している. 本来, この器具は加速屈曲時における内圧の調 整, 模擬血管の発振抑制の為に設けた。しかし支持棒近傍で は stent 拘束として作用し，ストラット同士磨耗及び破断部 位への応力集中を促し破損の要因となったと考えられる.

\section{2 高周波プラズマ ICP 発光分光分析によるステント金属 元秦溶出量検查}

Wall stentは 3.1 項で述べたように 7 種類金属元素から構 成されている.繰り返し疲労によるクラック生成などに伴い, これらの金属元素が試験溶液中へ溶出するかどうかを検出 するために ICP による検查を行った. その結果を Table 2 に 示す．破損が確認されなかった $10[\mathrm{~Hz}]$ 疲労試験では金属元 素の溶出は確認されなかったのに対し, 破損が生じたサンプ ルの溶液中からは ppm オーダーで検出された. 臨床時にお ける内膜増殖の影響も考慮しなければならないが、破損に伴 って金属成分が溶出するというリスクが推察された.

\section{4. 結語}

本研究では, 血管屈曲による繰り返し疲労を高周波で stent に作用する事が可能な試験装置の開発に成功した. また SEM, EPMA 及び ICP による検查は stent の疲労状態解析に有効な ツールである事が示された. 今後は血管ねじれや圧縮等によ る疲労を加速再現できる装置の開発及び評価にも着手する 予定である.

\section{文献}

1) Micheal R.Jaff : The Nature of the SFA, Endovascular Today October, 3-5, 2005

2) Richard R Heuser, Giancalo Biamino : PERIPHERAL VASCULAR STENTING second editionm, 98.102, 2005 3)井上旭 : 血液環境下における高分子製人工心臓弁の耐久性 の評価方法の検討, 早稲田大学修士論文, 2002, 8-22 暗辞

本研究は理工総研プロジェクト研究「05P29 先進医療実 現のための医工学的研究」及び, Boston Scientific Japan によるStent 提供を基に行った. 関係諸氏に厚くお礼申し上 げる.

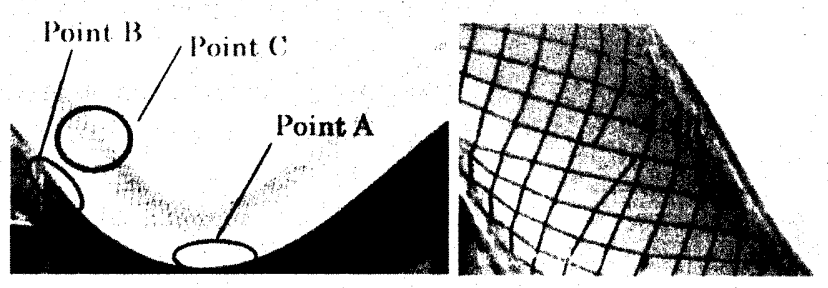

Fig.5 Fracture of stent fatigue corresponds to 36 months

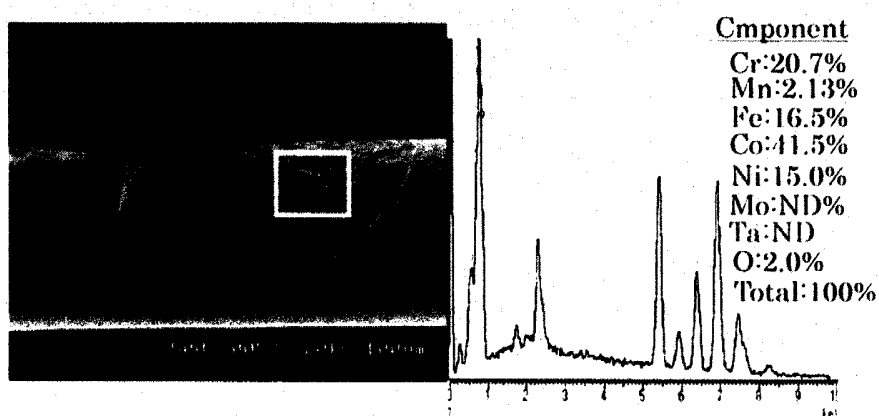

Fig.6 Result of SEM photograph and EPMA Analysis at position A

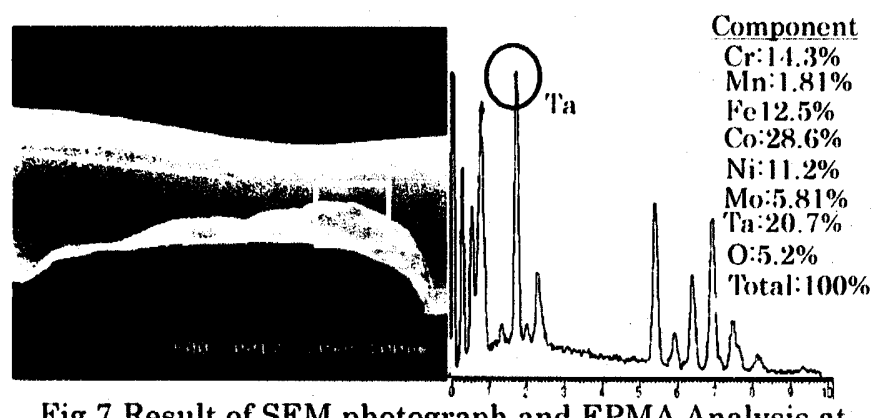

Fig. 7 Result of SEM photograph and EPMA Analysis at position $\mathrm{B}$
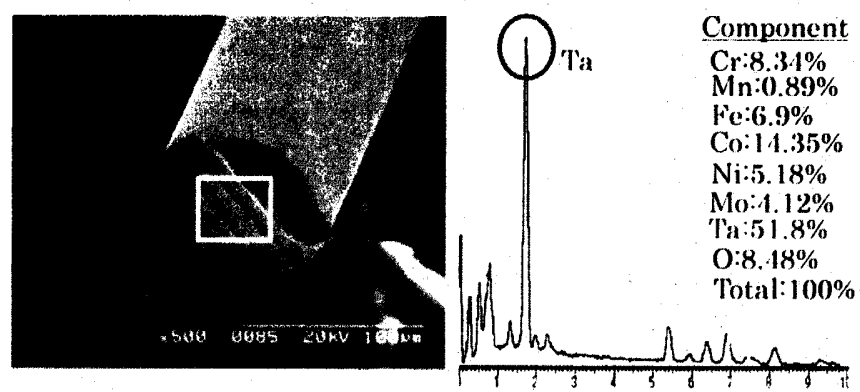

Fig.8 Result of SEM photograph and EPMA'Analysis ât position C(broken-out section)

Table2.Element analysis result by ICP

\begin{tabular}{c|c|c|c|c|c|c|c|c}
\hline \hline \multicolumn{2}{c|}{ Sample } & \multicolumn{6}{|c}{ Component [ppm] } \\
\hline \multicolumn{2}{c|}{ test Condition } & Co & Cr & Fe & Mo & Mn & Ni & Ta \\
\hline $10 \mathrm{~Hz}$ & equal to 6 month & ND & ND & ND & ND & ND & ND & ND \\
\hline $10 \mathrm{~Hz}$ & equal to 12 month & ND & ND & ND & ND & ND & ND & ND \\
\hline $40 \mathrm{~Hz}$ & $\begin{array}{c}\text { equal to 36 month } \\
\text { (Fructure) }\end{array}$ & 3.55 & 2.14 & 0.40 & 1.90 & 4.27 & 2.11 & ND \\
\hline
\end{tabular}

